\title{
THANKS FOR THE MEMORY
}

\author{
It's all in the mind.
}

\section{BY MILO JAMES FOWLER}

S kinner looked like an old vulture with a broken wing. He sat across the kitchen table from Amon with one arm crooked in a scarf bandage - a ruse that, the man insisted, made it easier for him to pass the sentinels with his crisp greenback bribes.

"Boring." Amon blinked, shoulders slumping with disappointment. He tugged the electrodes from his temples, and they retracted on threads spooling from Skinner's open valise. "You promised better."

"They're hard to come by, Sir."

Amon narrowed his hazel eyes. "But you're easily replaceable."

Skinner avoided the young Citizen's gaze. "I may have something you'll like." He busied himself with a set of electrodes wired to a separate receptacle inside the black leather bag.

"At additional cost, no doubt."

"Of course." Skinner cringed slightly and bared his yellow teeth in an attempt to lighten the mood. "Got my living to make, same as anybody else. But I can offer you a discount this evening - half off your second purchase."

"Show me what you've got." Amon gestured limply for the smuggler to speed things up. "No more murder and mayhem. I want more life."

Electrodes in hand, Skinner reached for the gentleman's forehead.

Amon leaned in. "Is it good?"

"Good, bad - what's the difference?" Skinner forced a chuckle.

Amon grabbed Skinner's gaunt wrist, electrodes dangling in midair. "One word from me, old man, and you will never leave the City. Answer me straight."

"What I mean, Sir, is that the memories themselves are often amoral in nature. A murder, for example. Taken from the mind of the victim's mother, it's the worst possible memory. But from the mind of the killer -"

"I've had quite enough death."

"Understood."

Master Amon had required Skinner's services on multiple occasions over the past few years, ever since the Wall had gone up around the City and President Hoover had mandated that all Citizens remain inside for their own protection. The Hoovervilles outside - as the rabble referred to them - were no place for men of means. But as everyday life behind the Wall stagnated, the wealthy had grown desperate for new sources of entertainment.

"I'm sure you will find this one to be a fine diversion from the norm. If you please."

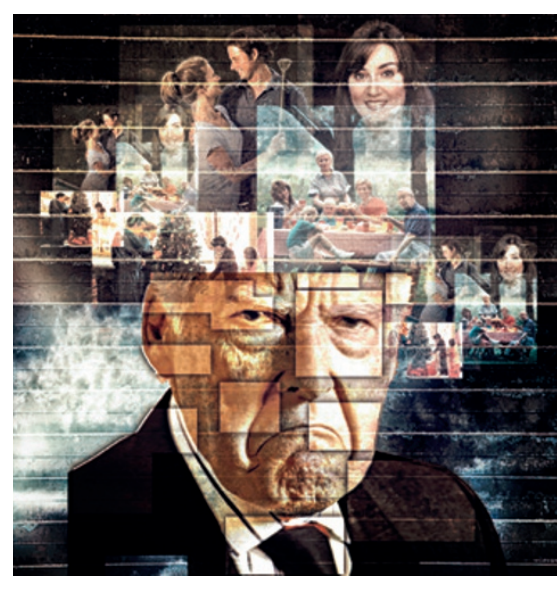

Amon released him. "How'd you come by it?"

"Do you really want to know?" Skinner attached the electrodes to Amon's temples.

Amon held his gaze.

"Very well." Skinner cleared his throat. "Some of the commoners have exhausted their supply of bad memories, so to speak. So they have had to resort to releasing good ones in light of their ... current hardships."

"Winter."

"When it means the difference between buying a warm coat and retaining a lingering memory of Grandma on Christmas morning - " Skinner noted the Citizen's look of disgust. "Not to worry. Considering how well you pay me, there will be no grandmotherly memories for you tonight."

Electrodes in place, Amon leaned back in his chair. "Glad to hear it."

Skinner reached into his bag. "Deep breaths now, Master Amon. You know the drill."

The Citizen shut his eyes and inhaled through his nostrils, waiting for the visions of another life to play through his mind like a motion picture at the theatre - but with full colour and sound.

The sentinel on duty frowned as he halted the Chrysler Six Roadster at the South Wall. Something about the driver didn't look quite right. But as the stoop-shouldered fellow at the wheel reached into his sling, the guard relaxed. When good money changed hands, few questions tended to surface.

"Quite a haul tonight." He pocketed the cash. $\rightarrow$ NATURE.COM

Follow Futures: @ @NatureFutures $f$ go.nature.com/mtoodm
The smuggler nodded without saying a word, his fedora pulled low.
Shrugging, the sentinel raised the gate and 근 waved the car through.

Gunning the engine, Amon glanced into the driver's side mirror as he tossed his hat onto the vacant passenger seat. He tugged off the makeshift sling and stretched his arm, reaching back for the bound and gagged man hidden under a throw rug.

“Time to wakey-wakey, Sacagawea." He punched Skinner in the gut and yanked the gag down around his neck, steering one-handed towards the shanties and tents that spread far beyond the reach of the car's headlights.

"Have you lost your mind?" Skinner sputtered.

"I'd be lost without you." As the Wall shrank behind them, Amon released a whoop. "I feel so alive!"

"What you're feeling now - it's not real. It wasn't your memory -"

"It's mine now. And I'm in love! You hear me?" He howled up at the Moon. "I've got to find her!"

"She won't know you from Madame Butterfly, Sir. And when the G-men find out you've flown the coop -"

Amon howled again.

Skinner sighed. In these harsh economic times, it was best not to give people false hope. Yet that's exactly what this Citizen was riding high on at the moment.

But he would crash back to reality in time. It was inevitable that he would return to his walled city after the throes of true love faded and dropped him into the depths of despair. Amon would suffer a low so devastating he could never hope to recover on his own.

And Skinner would be right there with his valise, when all Amon would demand were bad memories again, the variety that never allowed anyone to soar the heavens only to collapse into hell's yawning abyss.

Skinner cleared his throat. "Do you even know her name, Sir?"

Amon scoffed at such a foolish question. He and the woman were soul mates now, after all. "Florence," he swooned.

Skinner almost smiled. "Well, that's a start." -

Milo James Fowler is a teacher by day, writer by night. When he's not grading papers, he's imagining what the world might be like in dozens of alternate realities. www.milojamesfowler.com 